\title{
Influence of Basicity and FeO Content on Viscosity of Blast Furnace Type Slags Containing Fe0
}

\author{
Young Seok LEE, Dong Joon MIN, Sung Mo JUNG ${ }^{1)}$ and Sang Ho $\mathrm{Yl}^{21}$ \\ Department of Metallurgical Engineering, Yonsei University, Seoul 120-749, Korea. E-mail: chemical@yonsei.ac.kr \\ 1) Graduate School of Iron and Steel Technology, Pohang University of Science and Technology, Pohang 790-784, Korea. \\ 2) Technical Research Laboratories, POSCO, Pohang 790-785, Korea.
}

(Received on October 2, 2003; accepted in final form on April 22, 2004)

\begin{abstract}
The viscosities of $\mathrm{CaO}-\mathrm{SiO}_{2}-\mathrm{Al}_{2} \mathrm{O}_{3}-\mathrm{MgO}-\mathrm{FeO}$ slags were measured under conditions of $\mathrm{C} / \mathrm{S}=1.15-1.6$, 10-13 mass $\% \mathrm{Al}_{2} \mathrm{O}_{3}, 5-10$ mass $\% \mathrm{MgO}$ and 0-20 mass\% $\mathrm{FeO}$. Slag viscosity decreased with increasing $\mathrm{FeO}$ content at a fixed basicity $\left(\mathrm{CaO} / \mathrm{SiO}_{2}\right)$ of slag. Slag viscosity at low $\mathrm{FeO}(<7.5 \mathrm{mass} \% \mathrm{FeO})$ exhibited a minimum value by increasing $\mathrm{MgO}$ content in slag. Viscosity decreased with increasing slag basicity up to 1.3 while it increased as slag basicity increased from 1.3 to 1.5. It was proposed that the driving force for the decrease of slag viscosity would be an increase in depolymerization of silicate network at $C / S \leq 1.3$, while the viscous behavior at $\mathrm{C} / \mathrm{S}>1.3$ would be increased with increasing the chemical potential of primary solid phase e.g. dicalcium silicate. A thermodynamic approach for the activity of primary solid phase in molten slags resulted in a reasonable relationship between viscosity and slag components. Therefore, it was confirmed that slag viscosity in basic slags $(C / S>1.3)$ could be estimated by the chemical potential of dicalcium silicate.
\end{abstract}

KEY WORDS: viscosity; basicity; bosh slag; blast furnace; slag structure.

\section{Introduction}

Viscous behavior of blast furnace (BF) slags plays an important role to affect the operation efficiency since the flow pattern of molten slags has a significant influence on gas permeability, heat transfer, and the reduction of $\mathrm{SiO}_{2}$ and $\mathrm{FeO}$. Since the reduction of iron ores and the formation of slags with coke/coal ash proceed in the BF, basicity $\left(\mathrm{CaO} / \mathrm{SiO}_{2}\right)$ and $\mathrm{FeO}$ content in slags continuously change from the composition of initial sintered ore. Because the slags do not fully assimilate with ash in the bosh region of the blast furnace, they exhibit relatively high $\mathrm{CaO} / \mathrm{SiO}_{2}$ $(\mathrm{C} / \mathrm{S})$ ratios of about $\mathrm{C} / \mathrm{S}=1.4-1.6$ and $5-20 \mathrm{mass} \% \mathrm{FeO},{ }^{1,2)}$ which is compared with $\mathrm{C} / \mathrm{S} \approx 1.2$ and $\mathrm{FeO} \leq 0.2$ mass\% in tapped blast furnace slags. ${ }^{3)}$ A relatively high basicity of slag in bosh region is one of the main causes of slag formation problems. ${ }^{4}$

Although the viscosities of $\mathrm{CaO}-\mathrm{SiO}_{2}-\mathrm{Al}_{2} \mathrm{O}_{3}(-\mathrm{MgO})$ slags have been measured by several researchers, ${ }^{5-7)}$ the range of basicity in these studies was limited to approximately $\mathrm{C} / \mathrm{S} \approx 0.6-1.3$ in view of tapped slag composition. Recently, the viscosities of the $\mathrm{CaO}-\mathrm{SiO}_{2}-\mathrm{Al}_{2} \mathrm{O}_{3}-$ $\mathrm{MgO}-\mathrm{FeO}$ slags with $\mathrm{C} / \mathrm{S}=1.2-1.5$ were measured by Sugiyama. ${ }^{2)}$ However, the viscosities of slags containing $\mathrm{FeO}$ were measured only at $\mathrm{CaO} / \mathrm{SiO}_{2}=1.2$, and these results were applied to other basicity regions by extrapolation.

Therefore, in the present study, the viscosities of $\mathrm{CaO}-$ $\mathrm{SiO}_{2}-\mathrm{Al}_{2} \mathrm{O}_{3}-\mathrm{MgO}-\mathrm{FeO}$ slags were measured to clarify the viscous behavior of slag in $\mathrm{BF}$ under conditions of $\mathrm{C} / \mathrm{S}=1.15-1.6, \quad 10-13$ mass $\% \quad \mathrm{Al}_{2} \mathrm{O}_{3}, \quad 5-10$ mass $\% \mathrm{MgO}$ and $0-20$ mass $\% \mathrm{FeO}$ in terms of considering the reduction of iron ore. In addition, the thermodynamic approach based on experimental results was carried out in order to obtain the relationship between viscosity and slag components.

\section{Experimental}

\subsection{Preparation of Materials}

All slag samples were prepared using reagent-grade chemicals. In order to prepare the pre-melted slag, $100 \mathrm{~g}$ of mixed powder comprising $\mathrm{CaO}-\mathrm{SiO}_{2}-10 \mathrm{mass} \% \mathrm{Al}_{2} \mathrm{O}_{3}-$ $5 \mathrm{mass} \% \mathrm{MgO}\left(\mathrm{CaO} / \mathrm{SiO}_{2}=1.2\right)$, was pre-melted in a graphite crucible in an $\mathrm{Ar}(0.2 \mathrm{~L} / \mathrm{min})$ atmosphere at $1773 \mathrm{~K}$. Moisture and oxygen in Ar gas were removed by passing the gas through a $\mathrm{CaSO}_{4}$, silica gel and a column of magnesium turnings heated at $753 \mathrm{~K}$. The temperature was controlled within $\pm 2 \mathrm{~K}$ using a Pt-10mass $\% \mathrm{Rh} / \mathrm{Pt}-$ $13 \mathrm{mss} \% \mathrm{Rh}$ thermocouple and a proportional integral differential controller. After homogenization, the slag melt was quenched and was then crushed for later experiments.

\subsection{Apparatus and Procedure}

The rotating cylindrical method was employed for viscosity measurement. The experimental apparatus is shown in Fig. 1. A Brookfield digital viscometer (model LVDV$\mathrm{II}+$, Middleboro, MA), with a full-scale torque of $6.737 \times$ $10^{-5} \mathrm{~N} \cdot \mathrm{m}$, was used in the present study. The viscometer 


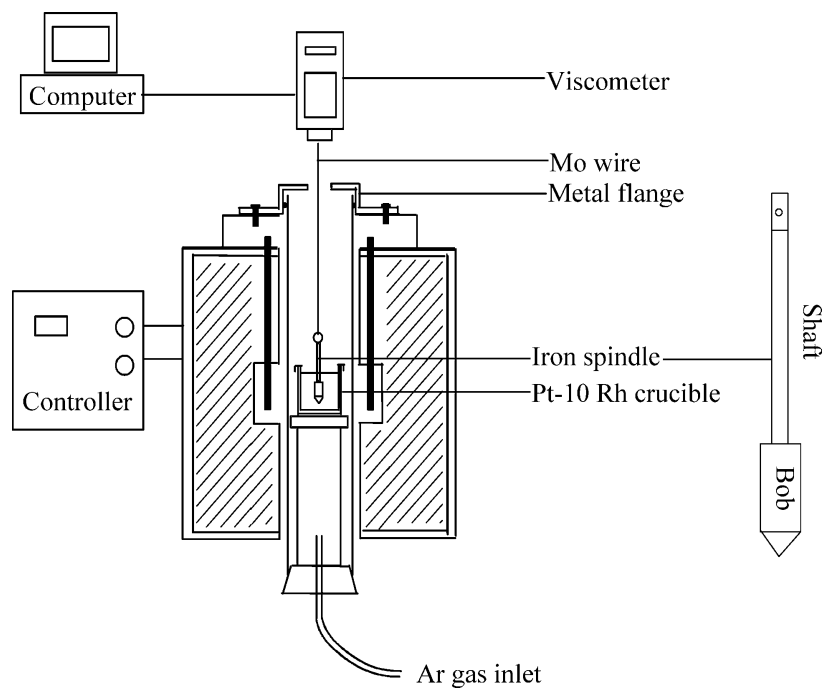

Fig. 1. Experimental apparatus for the measurement of slag viscosity. head was connected to the working spindle by a molybdenum wire ( $350 \mathrm{~mm}$ length, $1.5 \mathrm{~mm}$ diameter). The crucible used in the experiments was made of $\mathrm{Pt}-10 \mathrm{mass} \% \mathrm{Rh}$, and the spindle was made of pure iron in order to maintain an $\mathrm{Fe} / \mathrm{FeO}$ equilibrium state. The viscometer was calibrated at room temperature against Brookfield standard oils of 0.485 , $0.96,4.85$, and $9.75 \mathrm{dPa} \cdot \mathrm{s}$.

A metallic sealing flange was employed to fill the gap between the molybdenum wire and the mullite reaction tube, and $\operatorname{Ar}$ gas $(0.35 \mathrm{~L} / \mathrm{min})$ was flown into the reaction chamber to prevent the oxidation of the iron spindle and the suspending molybdenum wire.

115 to $120 \mathrm{~g}$ of slag samples for each measurement were prepared by adding proper amount of $\mathrm{CaO}, \mathrm{SiO}_{2}, \mathrm{Al}_{2} \mathrm{O}_{3}$, $\mathrm{MgO}$, and $\mathrm{FeO}$ powders to the pre-melted slag in order to adjust the slag composition listed in Table $\mathbf{1}$.

The crucible containing slag sample was then placed into the reaction chamber in an $\operatorname{Ar}(0.35 \mathrm{~L} / \mathrm{min})$ atmosphere at $1723 \mathrm{~K}$. The slag sample was molten for more than $3 \mathrm{~h}$ and

Table 1. Measured results for the viscosity of the $\mathrm{CaO}-\mathrm{SiO}_{2}-\mathrm{Al}_{2} \mathrm{O}_{3}-\mathrm{MgO}(-\mathrm{FeO})$ slags.

\begin{tabular}{|c|c|c|c|c|c|c|c|}
\hline \multirow{2}{*}{$\begin{array}{l}\text { Sample } \\
\text { Number }\end{array}$} & \multirow{2}{*}{$\mathrm{C} / \mathrm{S}$} & \multirow{2}{*}{$\mathrm{Al}_{2} \mathrm{O}_{3}$} & \multirow{2}{*}{$\mathrm{MgO}$} & \multirow{2}{*}{$\mathrm{FeO}$} & \multicolumn{3}{|c|}{ Viscosity(dPa.s) } \\
\hline & & & & & $1723 \mathrm{~K}$ & $1698 \mathrm{~K}$ & $1673 \mathrm{~K}$ \\
\hline 1 & 1.6 & 10 & 5 & 20 & 2.2 & 2.9 & 5.1 \\
\hline 2 & 1.6 & 10 & 7 & 20 & 2.6 & 3.1 & 3.7 \\
\hline 3 & 1.6 & 10 & 10 & 20 & 2.6 & 3.0 & \\
\hline 4 & 1.6 & 10 & 5 & 10 & 8.4 & 14.1 & 20.3 \\
\hline 5 & 1.6 & 10 & 7 & 10 & 7.9 & 8.0 & 9.5 \\
\hline 6 & 1.6 & 10 & 10 & 10 & 3.6 & 4.3 & \\
\hline 7 & 1.5 & 10 & 5 & 5 & 14.4 & 18.8 & \\
\hline 8 & 1.5 & 10 & 5 & 7.5 & 5.7 & 10.6 & \\
\hline 9 & 1.5 & 10 & 5 & 10 & 3.2 & 6.5 & 10.6 \\
\hline 10 & 1.5 & 10 & 7 & 5 & 10.4 & 12.9 & \\
\hline 11 & 1.5 & 10 & 7 & 7.5 & 4.1 & 6.2 & \\
\hline 12 & 1.5 & 10 & 7 & 10 & 2.4 & 3.8 & 8.6 \\
\hline 13 & 1.5 & 10 & 7 & 20 & 0.9 & 1.0 & 1.8 \\
\hline 14 & 1.5 & 10 & 10 & 5 & 20.3 & & \\
\hline 15 & 1.5 & 10 & 10 & 7.5 & 5.4 & 12.9 & \\
\hline 16 & 1.5 & 10 & 10 & 10 & 3.4 & 14.4 & \\
\hline 17 & 1.45 & 10 & 3.5 & 5 & 6.8 & 12.2 & \\
\hline 18 & 1.45 & 10 & 5 & 5 & 4.8 & 9.0 & 15.8 \\
\hline 19 & 1.45 & 10 & 7 & 5 & 9.2 & 13.7 & \\
\hline 20 & 1.45 & 10 & 10 & 5 & 6.1 & & \\
\hline 21 & 1.4 & 10 & 7 & 5 & 3.7 & 5.4 & 11.0 \\
\hline 22 & 1.3 & 10 & 5 & 5 & 3.3 & 3.3 & 4.2 \\
\hline 23 & 1.3 & 10 & 7 & 5 & 3.0 & 3.0 & 3.7 \\
\hline 24 & 1.3 & 10 & 10 & 5 & 2.8 & 4.7 & \\
\hline 25 & 1.3 & 10 & 5 & 0 & 5.7 & 6.5 & 10.4 \\
\hline 26 & 1.2 & 13 & 5 & 0 & 3.2 & & \\
\hline 27 & 1.2 & 13 & 7 & 0 & 3.0 & & \\
\hline 28 & 1.2 & 13 & 10 & 0 & 2.6 & & \\
\hline 29 & 1.15 & 13 & 5 & 0 & 5.7 & 6.8 & 8.5 \\
\hline 30 & 1.15 & 13 & 7 & 0 & 5.4 & 6.1 & 7.6 \\
\hline 31 & 1.15 & 13 & 10 & 0 & 4.5 & 5.1 & 7.6 \\
\hline
\end{tabular}




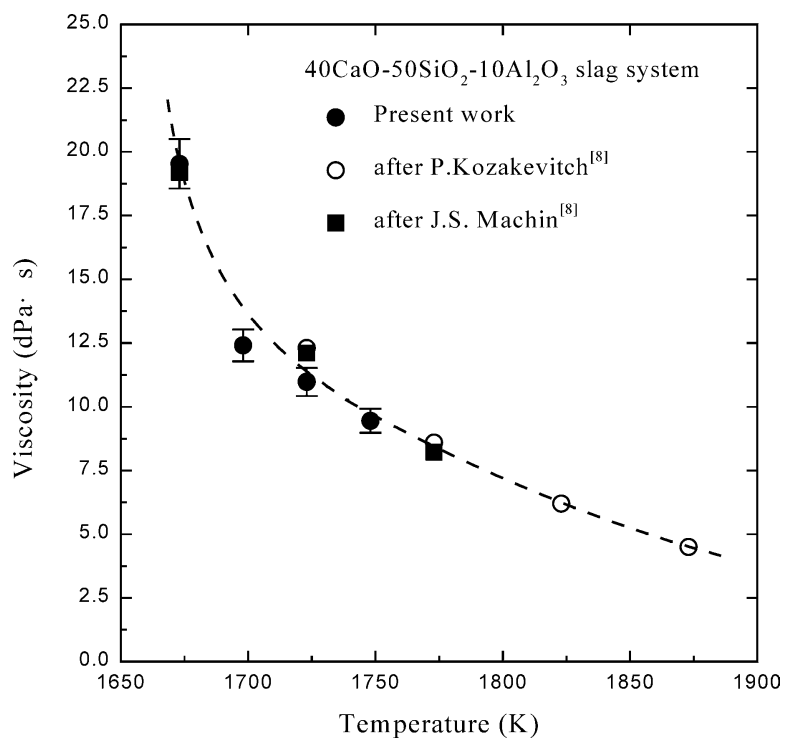

Fig. 2. Dependence of the viscosity of the $\mathrm{CaO}-\mathrm{SiO}_{2}-\mathrm{Al}_{2} \mathrm{O}_{3}$ slag on temperature.

the rotating spindle was immersed into the slag and located in the middle of the melt. Three different rotating speeds $(20,30$, and $60 \mathrm{rpm})$ were employed in $1723 \mathrm{~K}$ to ensure that the viscosity values were independent of the rotating speed and that the melt was homogeneous and behaving in a Newtonian manner at $1723 \mathrm{~K}$. The repeatability of the viscosity values obtained at $1723 \mathrm{~K}$ was higher than $99 \%$.

In order to confirm the reproducibility of slag viscosity values, some experiments for the same composition were carried out three times. The results showed that the standard deviation of the measured values at the same temperature increased from 0.5 to $4 \%$ with decreasing temperature from $1723 \mathrm{~K}$. Thus, in the present study, the only values measured at $1723 \mathrm{~K}$ were evaluated considering the discrepancy.

After viscosity measurements were completed, slag samples were reheated up to $1773 \mathrm{~K}$ and then quenched in flushing Ar stream in order to measure slag composition (by using X-ray Fluorescence: Bruker, SRS3400), slag structure (by using FT-IR spectroscopy: JASCO, FT/IR-300 E) and liquidus temperature (by using DTA: SETARAM, CS92-1618). According to the composition analysis of post-measurement slag as well as pre-measurement slag, there was no significant change in the slag compositions (less than $1 \%$ ).

The viscosity of the $\mathrm{CaO}-\mathrm{SiO}_{2}-10$ mass $\% \mathrm{Al}_{2} \mathrm{O}_{3}(\mathrm{C} / \mathrm{S}=$ $0.8)$ system was preliminarily measured and compared with the values reported in literature. ${ }^{8)}$ Figure 2 confirms that the viscosity values measured in the present study are reasonable.

\section{Results and Discussion}

\subsection{Measurement of Slag Viscosity}

Experimental results are summarized in Table 1. Viscosity of molten slag linearly increases with decreasing temperature and abruptly increases at a specific temperature, which has been known as crystallization temperature or solidification temperature, etc. ${ }^{9)}$ This temperature ther-

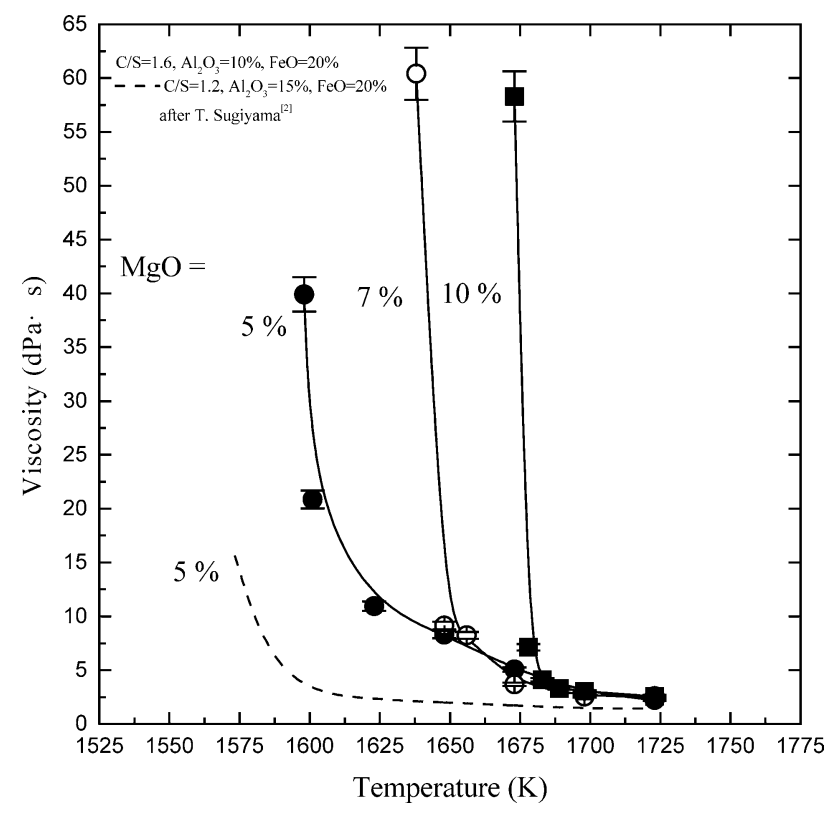

Fig. 3. Viscosities of $\mathrm{CaO}-\mathrm{SiO}_{2}-\mathrm{Al}_{2} \mathrm{O}_{3}-\mathrm{MgO}-\mathrm{FeO}$ system at $\mathrm{C} / \mathrm{S}=1.6$ with varying the content of $\mathrm{MgO}$ as a function of temperature.

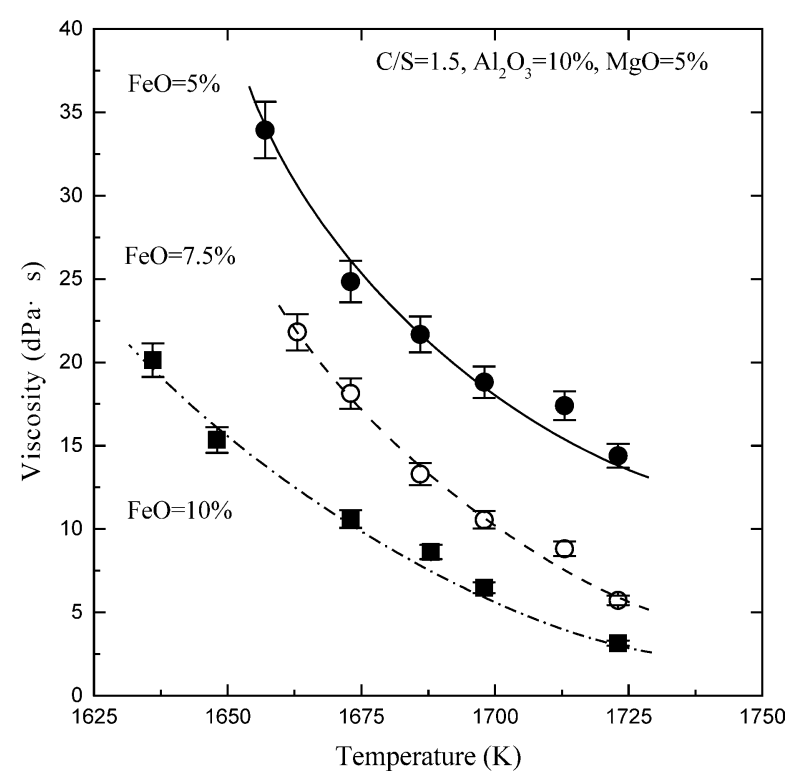

Fig. 4. Viscosities of $\mathrm{CaO}-\mathrm{SiO}_{2}-\mathrm{Al}_{2} \mathrm{O}_{3}-\mathrm{MgO}-\mathrm{FeO}$ system at $\mathrm{C} / \mathrm{S}=1.5$ with varying the content of $\mathrm{FeO}$ as a function of temperature.

modynamically coincides with the liquidus temperature at which the activity of primary solid phase approaches unity (It means that a primary solid phase precipitates). The effects of $\mathrm{MgO}$ and $\mathrm{FeO}$ content on slag viscosities are shown as a function of temperature in Figs. 3 and 4, respectively. In Fig. 3, MgO content does not significantly affect viscosity in the fully liquid region, but has a remarkable influence on crystallization temperature. The crystallization temperature is shifted to higher temperatures with increasing $\mathrm{MgO}$ content in slags. These phenomena can be caused by changing the chemical potential of primary solid phase, such as melilite $\left(2 \mathrm{CaO} \cdot \mathrm{MgO} \cdot 2 \mathrm{SiO}_{2}-2 \mathrm{CaO} \cdot \mathrm{Al}_{2} \mathrm{O}_{3} \cdot \mathrm{SiO}_{2}\right)$ or merwinite $\left(3 \mathrm{CaO} \cdot \mathrm{MgO} \cdot 2 \mathrm{SiO}_{2}\right)$, which can be an initial primary solid phase in the slag compositions investigated. On the 


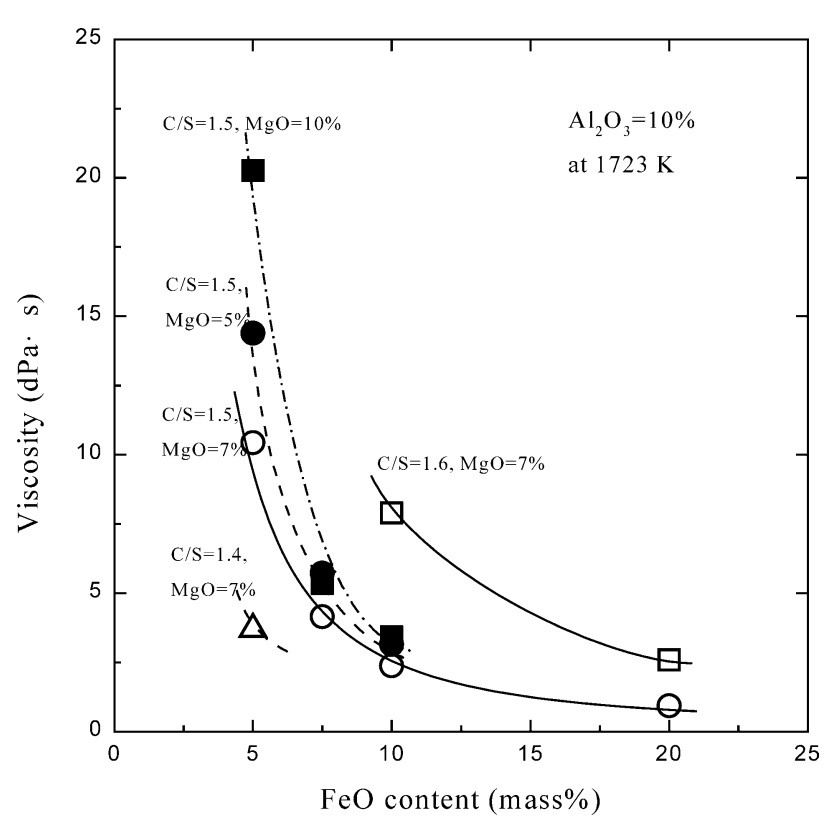

Fig. 5. Viscosities of $\mathrm{CaO}-\mathrm{SiO}_{2}-\mathrm{Al}_{2} \mathrm{O}_{3}-\mathrm{MgO}-\mathrm{FeO}$ system as a function of the content of $\mathrm{FeO}$ at $1723 \mathrm{~K}$.

other hand, in Fig. 4, an increase of $\mathrm{FeO}$ content results in decreasing the crystallization temperature and slag viscosity at $1723 \mathrm{~K}$. It can be expected from the fact that $\mathrm{FeO}$ having lower melting temperature than other oxides causes to increase the coexisting region of solid and liquid. ${ }^{10)}$

Dependence of slag viscosity on $\mathrm{FeO}$ content and slag basicity at $1723 \mathrm{~K}$ is shown in Fig. 5. The slag viscosities measured at a basicity of $\mathrm{C} / \mathrm{S}=1.5$ and 7 mass $\% \mathrm{MgO}$ increase from about 2.5 to $10 \mathrm{dPa} \cdot \mathrm{s}$ as $\mathrm{FeO}$ content decreases from 10 to 5 mass $\%$. The slag viscosity increases with increasing basicity from 1.4 to 1.6 at a fixed $\mathrm{MgO}$ and $\mathrm{FeO}$ content. As shown in Fig. 5, the typical bosh slags containing $\mathrm{FeO}$ content less than 7.5 mass $\%$ exhibit relatively high viscosity, because the effect of basicity and $\mathrm{MgO}$ on the slag viscosity is believed to be dominant. Therefore, the slag fluidity in BF bosh level could be affected by the reduction rate of iron ore. Toop and Samis reported that in $\mathrm{CaO}-\mathrm{FeO}-\mathrm{SiO}_{2}$ melts, $\mathrm{FeO}$ does not associate with the silicate groups in the low basicity region $(\mathrm{C} / \mathrm{S} \leq 1.86)$ but supplies free $\mathrm{Fe}^{2+}$ and $\mathrm{O}^{2-}$ ions to the silicate melts and causes the mixing entropy of silicate melt to increase. ${ }^{11)}$ It was also reported that $\mathrm{FeO}$ lowers the melting temperature of slags. ${ }^{12)}$ Thus, it can be suggested that the effect of $\mathrm{FeO}$ on the Gibbs free energy of mixing of molten slag would be more significant than those of other components, resulting in the decrease of melting temperatures and slag viscosities with increasing the $\mathrm{FeO}$ content.

In Fig. 6, the viscosities of $\mathrm{CaO}-\mathrm{SiO}_{2}-\mathrm{Al}_{2} \mathrm{O}_{3}-$ $\mathrm{MgO}(-\mathrm{FeO})$ slags are shown as a function of basicity. Viscosity exhibits a minimum value at about $\mathrm{C} / \mathrm{S}=1.3$. In general, an increase in basicity decreases the viscosity of slags, because silicate structure changes from the three dimensional network to discrete anionic groups containing simple chains and/or rings as basic oxides are increased. ${ }^{13,14)}$ This analysis is based on the polymerization degree of silicate network and can be employed to explain the trend of slag viscosity in the composition of $\mathrm{C} / \mathrm{S} \leq 1.3$. On the other hand, the slag viscosities increase with in-

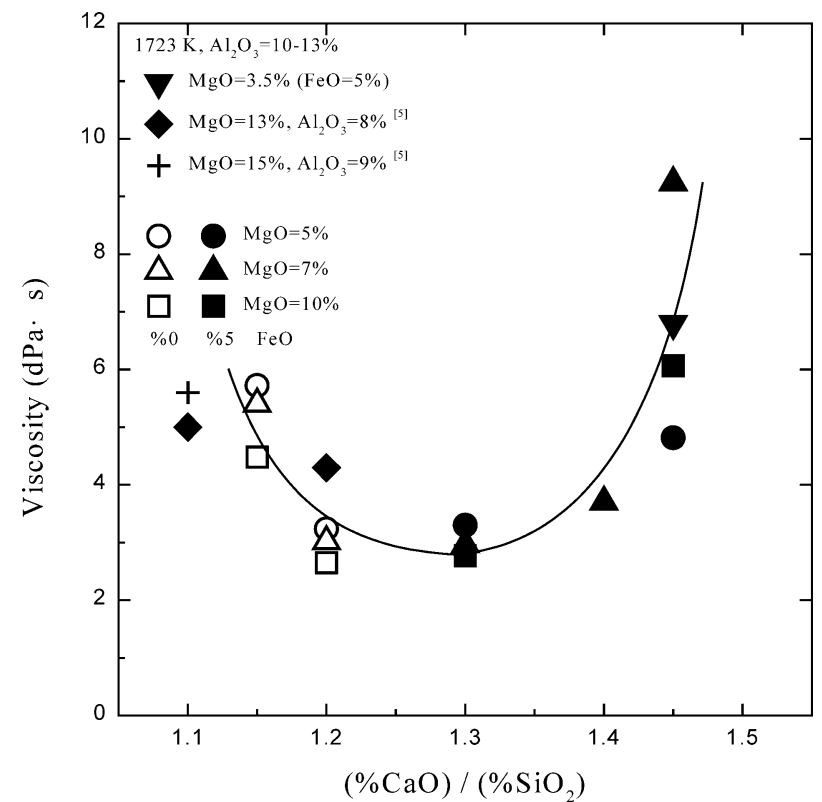

Fig. 6. Viscosities of $\mathrm{CaO}-\mathrm{SiO}_{2}-\mathrm{Al}_{2} \mathrm{O}_{3}-\mathrm{MgO}(-\mathrm{FeO})$ system as a function of the basicity at $1723 \mathrm{~K}$.

creasing basicity at $\mathrm{C} / \mathrm{S}>1.3$, which cannot be explained by the depolymerization of the silicate network. This may be explained by the effect of the chemical potential of primary solid phase, i.e. $2 \mathrm{CaO} \cdot \mathrm{SiO}_{2}$, on viscosity because the viscosity isotherms with composition are similar to phase diagrams of alloy and slag system. ${ }^{15,16)}$

The viscous flow of relatively high basic slags can be understood by the effect of cation-anion interaction on viscosity. ${ }^{10)}$ This type of interaction is the most prominent at the compositions where stable compounds are formed at lower temperatures. $^{10,16,17)}$ The effect of clustering at specific compositions on the variation of viscosity with composition has been found in the systems such as $\mathrm{FeO}-\mathrm{SiO}_{2},{ }^{18)} \mathrm{PbO}-$ $\mathrm{SiO}_{2}{ }^{19)}$ and $\mathrm{Na}_{2} \mathrm{O}-\mathrm{SiO}_{2}{ }^{20)}$ In these systems, a peak in the viscosity is shown at the compound formation compositions at the temperatures higher than the liquidus. In the $\mathrm{FeO}-\mathrm{SiO}_{2}$ system, a local maximum has been observed at the fayalite composition from 1573 to $1673 \mathrm{~K}$. This effect is more outstanding at lower temperatures. Thus, in the present study, the behavior of slag viscosity in the composition of $\mathrm{C} / \mathrm{S}>1.3$ at $1723 \mathrm{~K}$ can be affected by the cation-anion interaction corresponding to slag composition of solid compound such as dicalcium silicate, melilite, merwinite, etc. and can be explained qualitatively by the chemical potential for the formation of solid compound. It will be discussed in Sec. 3.2, later.

Figure 7 shows the effect of $\mathrm{MgO}$ and $\mathrm{FeO}$ on the slag viscosities measured at $1723 \mathrm{~K}$. The addition of $\mathrm{MgO}$ does not affect the slag viscosities obtained at $\mathrm{FeO}$ content greater than 7.5 mass $\%$, while a minimum value is observed at about 7 mass $\% \mathrm{MgO}$ with 5 mass $\% \mathrm{FeO}$. Mudersbach et al. reported that the viscosity of $\mathrm{CaO}-\mathrm{SiO}_{2}-\mathrm{Al}_{2} \mathrm{O}_{3}-\mathrm{MgO}$ slags exhibited a minimum value by increasing $\mathrm{MgO}$ content at a fixed basicity $(\mathrm{C} / \mathrm{S}=1.1)$ and $\mathrm{Al}_{2} \mathrm{O}_{3}$ content. ${ }^{21)}$ It is believed that $\mathrm{MgO}$ would behave as a network modifier in the composition less than 7 mass $\%$, while $\mathrm{MgO}$ contributes to an increase of the slag melting point, resulting in the increase of slag viscosity at higher than 7 mass $\%$ of $\mathrm{MgO}$. 


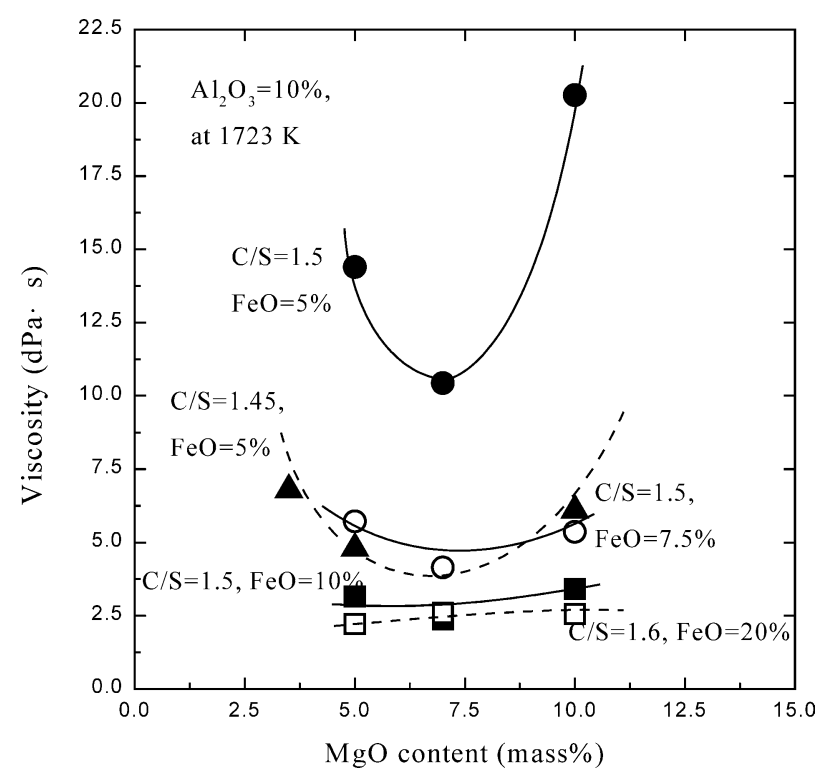

Fig. 7. Viscosities of $\mathrm{CaO}-\mathrm{SiO}_{2}-\mathrm{Al}_{2} \mathrm{O}_{3}-\mathrm{MgO}-\mathrm{FeO}$ system as a function of $\mathrm{MgO}$ content at $1723 \mathrm{~K}$.

\subsection{Relationship between Slag Components and Vis- cous Behavior of Bosh Slag}

The viscosity models in literature have been reviewed and employed for the viscosity calculation of slags being dealt with in the present work. ${ }^{2,22-25)}$ Most of the models in literature have been developed based on the fundamental concept related to the network modifier, network former, and amphoteric components. The current model was also formulated on the basis of the depolymerization mechanism of the silicate network, where the slag viscosity continuously decreases with increasing the content of the network modifier (basic oxide).

Figure 8 shows the dependence of slag viscosity on the slag basicity at 1723 and $1773 \mathrm{~K}$. The slag viscosity at $1773 \mathrm{~K}$ continuously decreases with increasing basicity up to about 1.2 and a decreasing rate of viscosity decreases at the higher basicity than $\mathrm{C} / \mathrm{S}=1.2$. On the other hand, the viscosity at $1723 \mathrm{~K}$ exhibits a minimum value at about $\mathrm{C} / \mathrm{S}=1.3$. This means that the slag viscosity in a wide range of basicity could not be described by only the depolymerization mechanism.

In order to study this viscous behavior in detail, the investigation using infrared spectra and the measurement of liquidus temperature $\left(T_{\mathrm{LQ}}\right)$ using DTA were carried out for these samples. Figure 9 exhibits the infrared spectra of the $\mathrm{CaO}-\mathrm{SiO}_{2}-12$ mass $\% \mathrm{Al}_{2} \mathrm{O}_{3}-7$ mass $\% \mathrm{MgO}(-5 \mathrm{mass} \% \mathrm{FeO})$ slags as a function of wave number $\left(\mathrm{cm}^{-1}\right)$ at different $\mathrm{C} / \mathrm{S}$ ratio. As the $\mathrm{C} / \mathrm{S}$ ratio increases from 0.9 to 1.45 , the IR bands for $\left[\mathrm{SiO}_{4}\right]$-tetrahedra with non-bridging oxygen per silicon $(\mathrm{NBO} / \mathrm{Si})=1,2,3$ and $4(1030,980,940$ and $850 \mathrm{~cm}^{-1}$ bands, respectively) become prominent. ${ }^{26)}$ And, the relative intensity of the IR bands for $\left[\mathrm{SiO}_{4}\right]$-tetrahedra with $\mathrm{NBO} / \mathrm{Si}=3+4$ increases with increasing the $\mathrm{C} / \mathrm{S}$ ratio, while that of the IR bands for $\left[\mathrm{SiO}_{4}\right]$-tetrahedra with $\mathrm{NBO} / \mathrm{Si}=1+2$ decreases with increasing the slag basicity. Also, the center of gravity of the $\left[\mathrm{SiO}_{4}\right]$-tetrahedral bands at about $1170-750 \mathrm{~cm}^{-1}$ shifts from about 980 to $940 \mathrm{~cm}^{-1}$ and an increase in a $\mathrm{C} / \mathrm{S}$ ratio results in shifting of lower limit IR bands for the $\left[\mathrm{SiO}_{4}\right]$-tetrahedra from 760-730

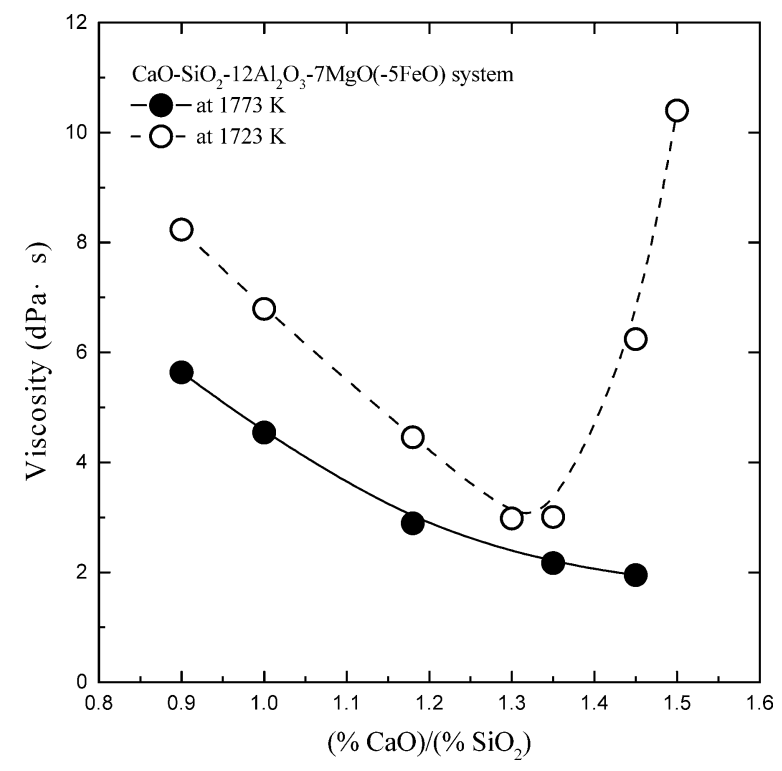

Fig. 8. Viscosities of $\mathrm{CaO}-\mathrm{SiO}_{2}-\mathrm{Al}_{2} \mathrm{O}_{3}-\mathrm{MgO}(-\mathrm{FeO})$ system as a function of the basicity at 1773 and $1723 \mathrm{~K}$.

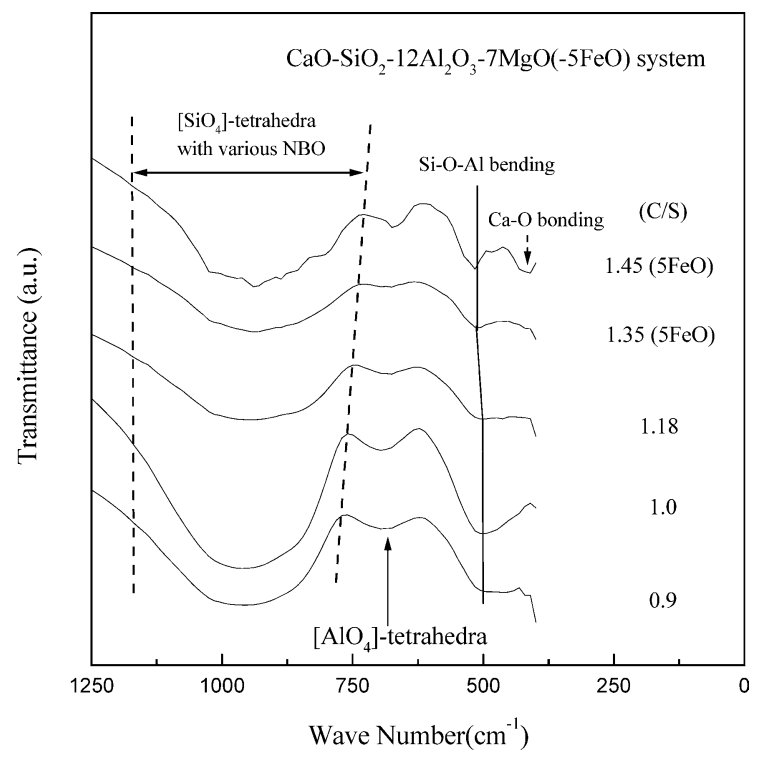

Fig. 9. The infrared spectra of the $\mathrm{CaO}-\mathrm{SiO}_{2}-12 \% \mathrm{Al}_{2} \mathrm{O}_{3}-$ $7 \% \mathrm{MgO}(-5 \% \mathrm{FeO})$ slags as a function of wave number $\left(\mathrm{cm}^{-1}\right)$ at different $\mathrm{C} / \mathrm{S}$ ratio.

$\mathrm{cm}^{-1}$. These results indicate that the degree of polymerization of silicate units continuously decreases with increasing the $\mathrm{C} / \mathrm{S}$ ratio from 0.9 to $1.45 .^{26)}$ Thus, the slag viscosity should be decreased as the $\mathrm{C} / \mathrm{S}$ ratio increases. However, the viscosity at $1723 \mathrm{~K}$ increases at the higher $\mathrm{C} / \mathrm{S}$ than about 1.3 in Fig. 8. Of course, because the liquidus temperature of slag is increased by increasing the $\mathrm{C} / \mathrm{S}$ ratio, the slag phase at $1723 \mathrm{~K}$ may become the coexisting phase of solid and liquid, resulting in increasing the viscosity at $1723 \mathrm{~K}$. However, it cannot be concluded that the viscous behavior of slag at $\mathrm{C} / \mathrm{S}>1.3$ is resulted from it without considering the melting temperature of slag.

Figure 10 shows the liquidus temperatures of the $\mathrm{CaO}-$ $\mathrm{SiO}_{2}-12$ mass $\% \mathrm{Al}_{2} \mathrm{O}_{3}-7$ mass $\% \mathrm{MgO}(-5 \mathrm{mass} \% \mathrm{FeO}) \quad$ slags as a function of the slag basicity. In Fig. 10, it can be known that the liquidus temperature is lower than $1723 \mathrm{~K}$ and any solid compound does not precipitate at those slag 


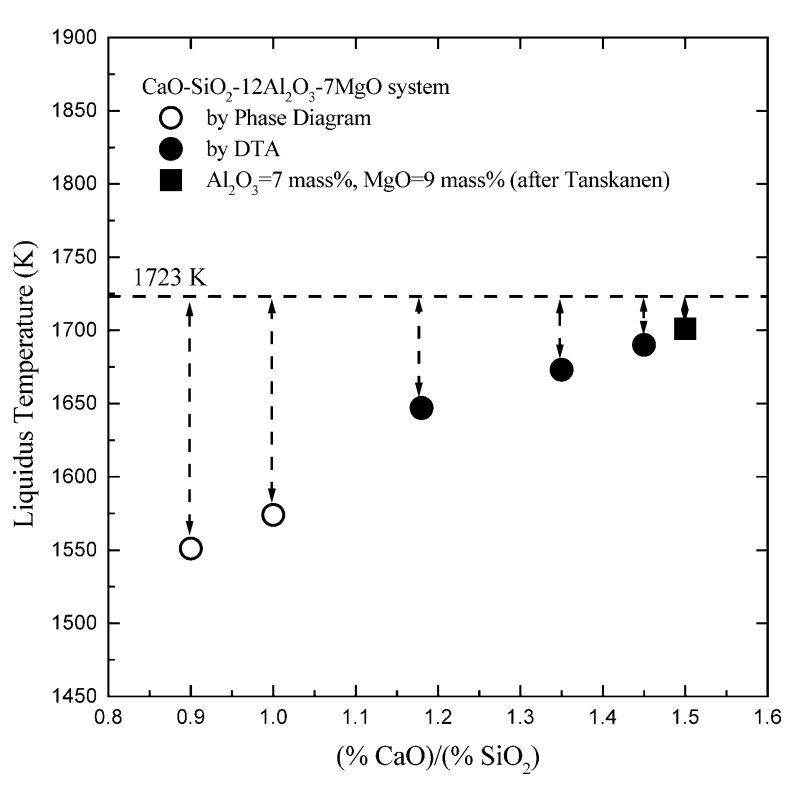

Fig. 10. The liquidus temperatures of the $\mathrm{CaO}-\mathrm{SiO}_{2}-$ $12 \% \mathrm{Al}_{2} \mathrm{O}_{3}-7 \% \mathrm{MgO}(-5 \% \mathrm{FeO})$ slags as a function of the slag basicity.

composition. Also, it is observed in Fig. 10 that the difference between the $T_{\mathrm{LQ}}$ and the experimental temperature $(1723 \mathrm{~K})$ decreases from about 175 to $35 \mathrm{~K}$ with increasing the $\mathrm{C} / \mathrm{S}$ ratio from 0.9 to 1.5 and is especially below $50 \mathrm{~K}$ at above $\mathrm{C} / \mathrm{S}=1.35$. Therefore, it indicates that the slag viscosity can be affected by not only the depolymerization mechanism of silicate network but also the other mechanism although a slag behaves as a homogeneous liquid at a fixed temperature.

In general, silicate structure changes from the three dimensional network to discrete anionic groups containing simple chains and/or rings according to an increase in $\mathrm{CaO}$ content. If the content of $\mathrm{CaO}$ greater than a specific composition increases, the silicate network will be sufficiently dissociated and the melting temperature of slag will be increased. However, it can cause the liquid slag to contract, resulting in increasing the frictional force between the silicate units because the nearest-neighbor distances and coordination numbers in the liquid state at or near the melting temperature are closely similar to those in the solid state ${ }^{17,27)}$; the increased $\mathrm{Ca}^{2+}$ ions can bind the dissociated silicate anions because of the electrical interaction between cation and anion as if the bond between two $\mathrm{Ca}^{2+}$ or more and $\left[\mathrm{SiO}_{4}\right]^{4-}$ comprising solid phase is loosened. In Fig. 9, it can be known that the relative intensity of the IR bands for $\left[\mathrm{SiO}_{4}\right]$-tetrahedra with $\mathrm{NBO} / \mathrm{Si}=3+4$ becomes prominent at $\mathrm{C} / \mathrm{S}=1.45$ and excess $\mathrm{Ca}^{2+}$ ion exists at $\mathrm{C} / \mathrm{S}=1.45$ from the peak of $\mathrm{Ca}-\mathrm{O}$ bonding at about $420 \mathrm{~cm}^{-1}{ }^{26}$, Therefore, from Figs. 8 to 10, the behavior of viscosity with $\mathrm{C} / \mathrm{S}>1.3$ can be affected by the liquid structure similar to the structure of solid formed at lower temperatures although the silicate structure become simpler and smaller. In the present study, it was assumed that the viscosity would be decreased by the depolymerization of silicate network with increasing the $\mathrm{C} / \mathrm{S}$ ratio at $\mathrm{C} / \mathrm{S} \leq 1.3$, while that of slag at $\mathrm{C} / \mathrm{S}>1.3$ would be increased by the liquid structure related to the structure of primary solid phase e.g. dicalcium silicate as the slag basicity increases.

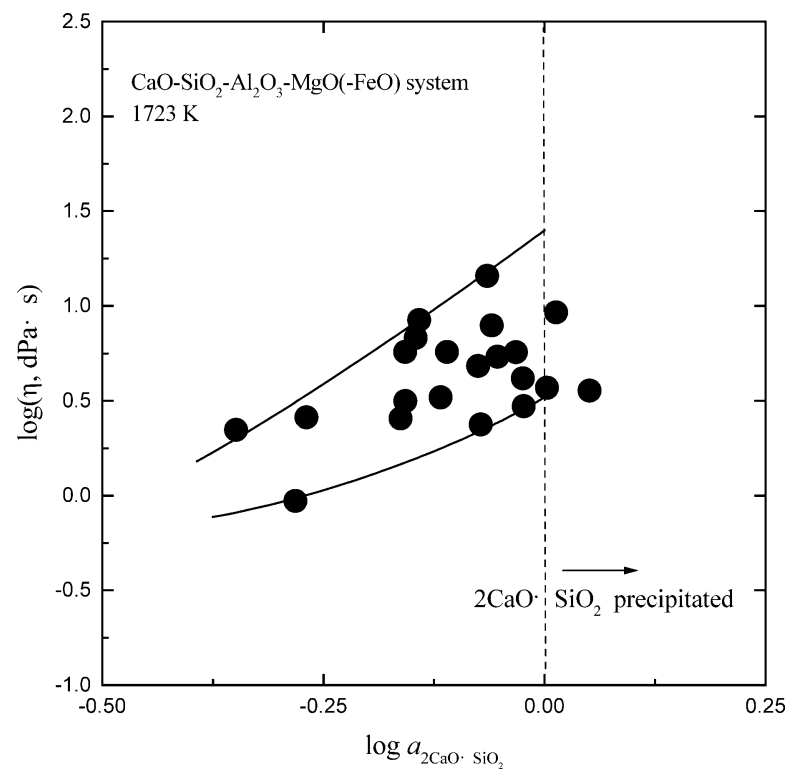

Fig. 11. Dependence of slag viscosity on the activity of $2 \mathrm{CaO} \cdot \mathrm{SiO}_{2}$ in liquid slags at $1723 \mathrm{~K}$.

Fredericci et al. concluded that the initial precipitating solid phases were merwinite $\left(3 \mathrm{CaO} \cdot \mathrm{MgO} \cdot \mathrm{SiO}_{2}\right)$, melilite $\left(2 \mathrm{CaO} \cdot \mathrm{MgO} \cdot 2 \mathrm{SiO}_{2}-2 \mathrm{CaO} \cdot \mathrm{Al}_{2} \mathrm{O}_{3} \cdot \mathrm{SiO}_{2}\right)$ and dicalcium silicate $\left(2 \mathrm{CaO} \cdot \mathrm{SiO}_{2}\right)$ in the blast furnace slags of $\mathrm{C} / \mathrm{S}=1.2$. $\left.^{28}\right)$ It was also reported that because the composition of bosh slags in the blast furnace ranges $1.3 \leq \mathrm{C} / \mathrm{S} \leq 1.5$, it can shift toward the primary field of dicalcium silicate. ${ }^{1)}$ In addition, a thermodynamic calculation by FACTSage ${ }^{\mathrm{TM}} 5.2$ (thermochemical software) for the present slag system indicates that dicalcium silicate could be a primary solid phase. Therefore, in the present study, it was assumed that the liquid structure in $\mathrm{C} / \mathrm{S}>1.3$ could affected by dicalcium silicate. And, the thermodynamic activity of $2 \mathrm{CaO} \cdot \mathrm{SiO}_{2}$ in molten slags was investigated to estimate the viscosity of relatively basic slags $(\mathrm{C} / \mathrm{S}>1.3)$ because a thermodynamic activity contains the structural and chemical meanings.

The standard free energy change for the formation of $2 \mathrm{CaO} \cdot \mathrm{SiO}_{2}$ is represented by Eq. (1):

$$
\begin{aligned}
& 2 \mathrm{CaO}(\mathrm{s})+\mathrm{SiO}_{2}(\mathrm{~s})=2 \mathrm{CaO} \cdot \mathrm{SiO}_{2}(\mathrm{~s}) \\
& \Delta G_{1}^{\circ}=-126400-5.02 T(\mathrm{~J} / \mathrm{mol})^{29)} \\
& K_{1}=\frac{a_{2 \mathrm{CaO} \cdot \mathrm{SiO}_{2}}}{a_{\mathrm{CaO}}^{2} \cdot a_{\mathrm{SiO}_{2}}}
\end{aligned}
$$

Equations (1) and (3) indicate that the activity of $2 \mathrm{CaO} \cdot \mathrm{SiO}_{2}$ in molten slags can be enhanced by increasing $a_{\mathrm{CaO}}$ in the slags at a fixed temperature. Furthermore, they indicate that the activity of $2 \mathrm{CaO} \cdot \mathrm{SiO}_{2}$ increases with increasing slag basicity $(\mathrm{C} / \mathrm{S})$ and can be evaluated based on the activities of $\mathrm{CaO}$ and $\mathrm{SiO}_{2}$ in the slags. The activity of each component was calculated by applying the regular solution model to the present slag system. ${ }^{30)}$ In Fig. 11, the relationship between the slag viscosity and activity of $2 \mathrm{CaO} \cdot \mathrm{SiO}_{2}$ at $1723 \mathrm{~K}$ is shown. Most of the calculated activities of $2 \mathrm{CaO} \cdot \mathrm{SiO}_{2}$ based on the activity values of $\mathrm{CaO}$ and $\mathrm{SiO}_{2}$ are less than unity at $1723 \mathrm{~K}$. It means that $2 \mathrm{CaO} \cdot \mathrm{SiO}_{2}$ was not precipitated in present experiments in view of thermodynamic calculation. Although the data are 
somewhat scattered in Fig. 11, the slag viscosity increases with increasing the activity of dicalcium silicate in slags. It indicates that the viscosity of relatively basic slags is affected by the chemical potential of primary solid phase, even in homogeneous liquid phase (even though solid compounds are not precipitated). Thus, in the present study, it was assumed that the slag viscosity could be expressed by the ratio of $2 \mathrm{CaO} \cdot \mathrm{SiO}_{2}$ activity to the stability factor affecting the formation of $2 \mathrm{CaO} \cdot \mathrm{SiO}_{2}$ in liquid slags by the following equation:

$$
\text { Slag viscosity } \propto \frac{\text { Activity of } 2 \mathrm{CaO} \cdot \mathrm{SiO}_{2}}{\text { Stability factor of } 2 \mathrm{CaO} \cdot \mathrm{SiO}_{2} \text { in slag }}
$$

In Eq. (4), the stability factor is the factor controlling the formation of $2 \mathrm{CaO} \cdot \mathrm{SiO}_{2}$. If other ions substitute for $\mathrm{Ca}^{2+}$ and silicate anion and occupy their sites, the interaction of $\mathrm{Ca}^{2+}$ and $\left[\mathrm{SiO}_{4}\right]^{4-}$ will be weakened and its number will be smaller. That is, the competition of $\mathrm{Ca}^{2+}$ and $\left[\mathrm{SiO}_{4}\right]^{4-}$ with other ions for the same sites can cause to be unstable formation of the $2 \mathrm{CaO} \cdot \mathrm{SiO}_{2}$. In the present study, this effect was defined as the stability factor of $2 \mathrm{CaO} \cdot \mathrm{SiO}_{2}$.

It is well known that $\mathrm{MgO}$ and $\mathrm{Al}_{2} \mathrm{O}_{3}$ decrease the region of $2 \mathrm{CaO} \cdot \mathrm{SiO}_{2}$ in slag. ${ }^{31,32)}$ It indicates that $\mathrm{Mg}^{2+}$ and aluminate anions can substitute for $\mathrm{Ca}^{2+}$ and silicate anions, respectively. Consequently, $\mathrm{MgO}$ and $\mathrm{Al}_{2} \mathrm{O}_{3}$ deteriorate the stability of $2 \mathrm{CaO} \cdot \mathrm{SiO}_{2}$. Because the bonding energy is higher as the formation enthalpy change negatively increases, it can be confirmed from the formation enthalpy changes per mole of $\mathrm{SiO}_{2}$ for solid compounds at $1723 \mathrm{~K}$, as follows ${ }^{33)}$.

$$
\begin{gathered}
\Delta H_{\mathrm{f}}\left(2 \mathrm{CaO} \cdot \mathrm{SiO}_{2}\right)=-99.7\left(\mathrm{~kJ} / \mathrm{mol} \mathrm{SiO}_{2}\right) \\
\Delta H_{\mathrm{f}}\left(3 \mathrm{CaO} \cdot \mathrm{MgO} \cdot 2 \mathrm{SiO}_{2}\right)=-127.0\left(\mathrm{~kJ} / \mathrm{mol} \mathrm{SiO}_{2}\right) \\
\Delta H_{\mathrm{f}}\left(2 \mathrm{CaO} \cdot \mathrm{Al}_{2} \mathrm{O}_{3} \cdot \mathrm{SiO}_{2}\right)=-127.7\left(\mathrm{~kJ} / \mathrm{mol} \mathrm{SiO}_{2}\right) \\
\Delta H_{\mathrm{f}}\left(2 \mathrm{CaO} \cdot \mathrm{MgO} \cdot 2 \mathrm{SiO}_{2}\right)=-100.1\left(\mathrm{~kJ} / \mathrm{mol} \mathrm{SiO}_{2}\right)
\end{gathered}
$$

Also, it can be assumed that $\mathrm{FeO}$ can disturb the encounter of $\mathrm{Ca}^{2+}$ with silicate anions because it increases the mixing entropy of slag system. Thus, it can be assumed that the stability factor controlling the formation of $2 \mathrm{CaO} \cdot \mathrm{SiO}_{2}$ in liquid slags comprises the activities of $\mathrm{MgO}, \mathrm{Al}_{2} \mathrm{O}_{3}$ and $\mathrm{FeO}$ in slag. That is, Eq. (4) can be expressed by the following equation:

$$
\eta \propto \frac{a_{2 \mathrm{CaO} \cdot \mathrm{SiO}_{2}}}{a_{\mathrm{MgO}} \times a_{\mathrm{Al}_{2} \mathrm{O}_{3}} \times a_{\mathrm{FeO}}}
$$

A variable, $F$, could be semi-empirically defined as Eq. (6) by using Eq. (5) and fitting with measured viscosity. That is, authors tried to find out the variable showing the best fit with measured viscosities. As the result, the $F$ among the other variables had a best linear correlation with the viscosities measured as shown in Fig. 12. However, Eq. (6) contains the mentioned relationship in Eq. (5) although the second term on the right-hand side of Eq. (6) was deduced during fitting.

$$
F=\log \frac{a_{2 \mathrm{CaO} \cdot \mathrm{SiO}_{2}}}{a_{\mathrm{Al}_{2} \mathrm{O}_{3}} \times a_{\mathrm{MgO}} \times a_{\mathrm{FeO}}}-\left(\frac{1.6}{\mathrm{C} / \mathrm{S}}\right)^{4}
$$

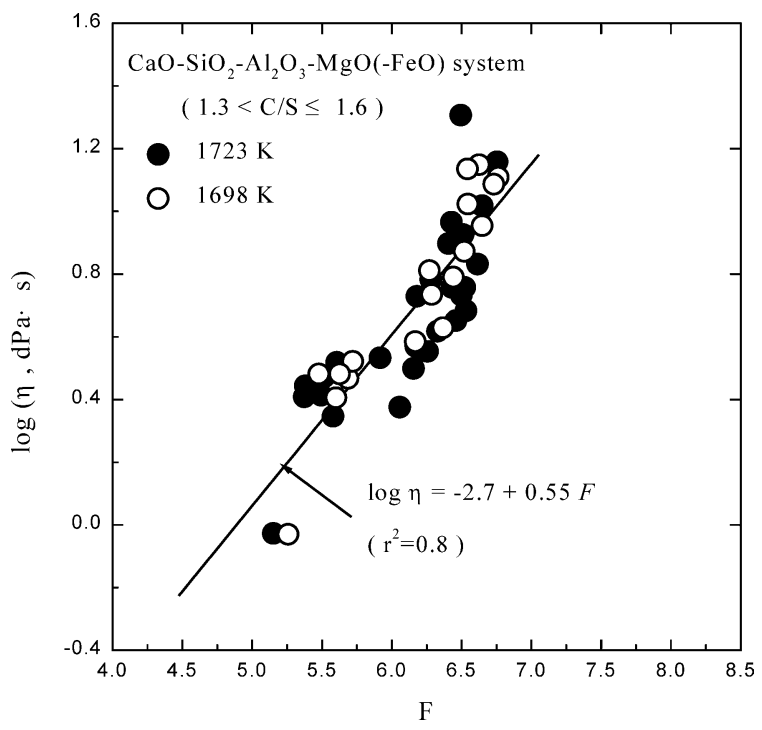

Fig. 12. Viscosities of slags as a function of $F$ at 1698 and $1723 \mathrm{~K}$.

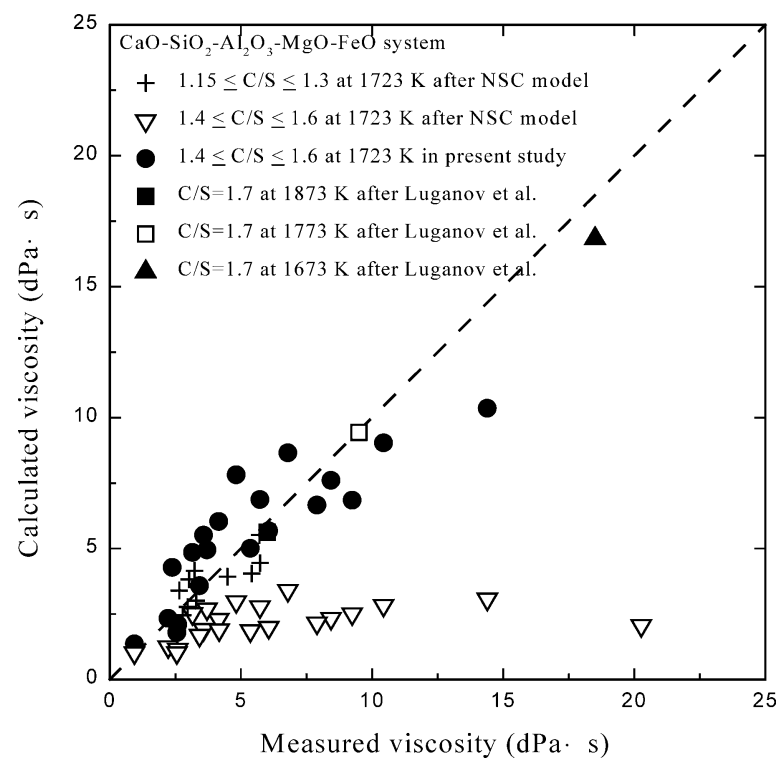

Fig. 13. Viscosities calculated from the present and NSC models as a function of measured data.

where the second term on the right-hand side of Eq. (6) may be understood as the background factor related to the variation of silicate structure with basicity. Thus, the semiempirical equation for predicting the viscosity of relatively basic slags $(\mathrm{C} / \mathrm{S}>1.3)$ could be given as Eq. (7) by fitting the relationship between the measured viscosity and $F$ as shown in Fig. 12.

$$
\log \eta(\mathrm{dPa} \cdot \mathrm{s})=-2.7+0.55 F\left(r^{2}=0.8,1.3<\mathrm{C} / \mathrm{S}<1.6\right)
$$

where Eq. (7) contains the temperature dependence of viscosity because the activity coefficients of each components in Eq. (6) was derived by the regular solution model ${ }^{30)}$ and those contains the temperature dependence.

The estimated viscosities of the $\mathrm{CaO}-\mathrm{SiO}_{2}-\mathrm{Al}_{2} \mathrm{O}_{3}-$ $\mathrm{MgO}-\mathrm{FeO}$ slags by the present equation and the NSC model $^{2)}$ are compared in Fig. 13. The viscosities predicted by the NSC model are in good agreement with the mea- 
sured data at $\mathrm{C} / \mathrm{S} \leq 1.3$ in this study. However, in the relatively basic slags $(\mathrm{C} / \mathrm{S}>1.3)$, there is significant difference between the calculated and measured values. On the other hand, it is observed that the viscosity at $\mathrm{C} / \mathrm{S}=1.7$ in the literature $^{34)}$ can be predicted by the present equation with little variation. Consequently, it was confirmed that the viscosity of relatively basic BF slags $(\mathrm{C} / \mathrm{S}>1.3)$ could be predicted by employing the thermodynamic concept based on the chemical potential of dicalcium silicates. However, it should need the more studies because the thermodynamic data and the liquidus temperature of the present slag system have been ambiguous, so far.

\section{Conclusions}

The viscosities of the $\mathrm{CaO}-\mathrm{SiO}_{2}-\mathrm{Al}_{2} \mathrm{O}_{3}-\mathrm{MgO}-\mathrm{FeO}$ slags were measured under conditions of $\mathrm{C} / \mathrm{S}=1.15-1.6,10-13$ mass $\% \mathrm{Al}_{2} \mathrm{O}_{3}, 5-10$ mass $\% \mathrm{MgO}$ and 5-20 mass $\% \mathrm{FeO}$. The viscosity of the $\mathrm{BF}$ type slag decreased by increasing the $\mathrm{FeO}$ content at a fixed basicity $\left(\mathrm{CaO} / \mathrm{SiO}_{2}\right)$ of slags. Slag viscosity at low $\mathrm{FeO}(<7.5 \mathrm{mass} \% \mathrm{FeO})$ exhibited a minimum value by increasing $\mathrm{MgO}$ content in slag. The addition of $\mathrm{MgO}$ does not affect the viscosity at $\mathrm{FeO} \geq 7.5$ mass $\%$, while a minimum value is observed at about 7 mass $\% \mathrm{MgO}$ with 5 mass $\% \mathrm{FeO}$.

Viscosity decreased with increasing slag basicity up to 1.3 while it increased as slag basicity increased from 1.3 to 1.5. Therefore, it was proposed that, with increasing the slag basicity, the driving force for the decreases of slag viscosity would be an increase in depolymerization of silicate network at $\mathrm{C} / \mathrm{S} \leq 1.3$, while the driving force for the increase of slag viscosity at $\mathrm{C} / \mathrm{S}>1.3$ is an increase in the chemical potential of solid compound such as dicalcium silicate.

The slag viscosities predicted by using the current model are in good agreement with the measured data for the low basicity $(\mathrm{C} / \mathrm{S} \leq 1.3)$, but in highly basic slags $(\mathrm{C} / \mathrm{S}>1.3)$, the calculated viscosities are significantly different from the measured values. However, in basic slags $(\mathrm{C} / \mathrm{S}>1.3)$, viscosities were affected by the chemical potential of dicalcium silicate calculated by applying a regular solution model. A thermodynamic approach for the activity of a primary solid phase $\left(2 \mathrm{CaO} \cdot \mathrm{SiO}_{2}\right)$ in molten slags on viscosity resulted in a reasonable relationship between viscous behavior of basic BF (i.e., bosh) slags and slag components.

\section{Acknowledgment}

This work received financial support from POSCO. And one of the authors (LYS) was supported by the Brain Korea 21 Project.

\section{REFERENCES}

1) G. Clixby: Ironmaking Conf. Proc., Vol. 36, ISS, Warrendale, PA, (1977), 308.

2) T. Sugiyama: Proc. 6th Int. Conf. Molten Slags, Fluxes, and Salts, KTH, Stockholm, (2000), CD-ROM paper 412.

3) E. T. Turkdogan: Trans. Iron Steel Inst. Jpn., 24 (1984), 591

4) L. S. Okvist: ISIJ Int., 41 (2001), 1429

5) J. S. Machin, T. B. Yee and D. C. Hanna: J. Am. Ceram. Soc., 35 (1952), 322.

6) U. N. Mishra, B. Thakur and M. N. Thakur: SEAISI Q., 23 (1994), 72.

7) K. C. Mills: Slag Atlas, 2nd ed., Verlag Stahleisen GmbH, Düsseldorf, (1995), 349.

8) T. Iida and Y. Shiraishi: Handbook of Physico-chemical Properties at High Temperatures, ISIJ, Tokyo, (1988), 130.

9) S. Sridhar, K. C. Mills, O. D. C. Afrange, H. P. Lorz and R. Carli: Ironmaking Steelmaking, 27 (2000), 238.

10) L. Zhang and S. Jahanshahi: Metall. Mater. Trans. B, 29B (1998), 187.

11) Q. W. Toop and C. S. Samis: Trans. Metall. Soc. AIME, 224 (1962), 878.

12) P. A. Tanskanen, S. M. Huttunen, P. H. Mannila and J. J. Harkki: Proc. 6th Int. Conf. Molten Slags, Fluxes, and Salts, KTH, Stockholm, (2000), CD-ROM paper 445.

13) J. O'M. Bockris and D. C. Lowe: Proc. Roy. Soc., (London), A, 226 (1954), 423.

14) L. Zhang and S. Jahanshahi: Metall. Mater. Trans. B, 29B (1998), 177.

15) S. Seetharaman and D. Sichen: ISIJ Int., 37 (1997), 109.

16) L. S. Darken: Trans. Metall. Soc. AIME, 239 (1967), 80.

17) T. Iida and R. I. L. Guthrie: The Physical Properties of Liquid Metals, Clarendon Press, Oxford, (1988), 147.

18) G. H. Kaiura, J. M. Toruri and G. Marchant: Can. Metall. Q., 16 (1977), 156.

19) H. Ito and T. Yanagase: Trans. Jpn. Inst. Met., 1 (1960), 115

20) G. Urbain, Y. Bottinga and P. Richet: Geochim. Cosmochim. Acta, 46 (1982), 1061.

21) D. Mudersbach, P. M. Drissen, M. Kunn and J. Geiseler: Steel Res., 72 (2001), 86.

22) G. Urbain: Steel Res., 58 (1987), 111

23) P. V. Riboud, Y. Roux, L. D. Lucas and H. Gaye: Fachber. Hättenprax. Metallweiterverarb., 19 (1981), 859.

24) K. C. Mills and S. Sridhar: Ironmaking Steelmaking, 26 (1999), 262.

25) K. C. Mills and B. J. Keene: Int. Mater. Rev., 32 (1987), 1.

26) J. H. Park, D. J. Min and H. S. Song: ISIJ Int., 42 (2002), 344.

27) F. D. Richardson: Physical Chemistry of Melts in Metallurgy, Vol. 1, Academic Press, London, (1974), 1

28) C. Fredericci, E. D. Zanotto and E. C. Ziemath: J. Non-Cryst. Solids, 273 (2000), 64.

29) O. Kubaschewski and C. B. Alcock: Metallurgical Thermochemistry, 5th ed., Pergamon Press, Oxford, (1983), 379.

30) S. Banya: ISIJ Int., 33 (1993), 2.

31) M. Kowalski, P. J. Spencer and D. Neuschütz: Slag Atlas, 2nd ed., Verlag Stahleisen GmbH, Düsseldorf, (1995), 21.

32) M. Lee and P. Barr: Steel Res., 73 (2002), 123.

33) I. Barin: Thermochemical Data of Pure Substances, VCH, Weinheim, Germany, (1989), 48, 304, 312, 323, 324, 327, 868, 1359.

34) V. A. Luganov, M. A. Turkeev and T. K. Ischanov: Metallurgia $i$ Obogashcheva, 12 (1977), 75. 